\title{
Evaluating the frequency of anatomical variations of the sinonasal region in pediatric and adult age groups according to gender: computed tomography findings of 1532 cases
}

\author{
Adem Bora* (iD, Merve Koç(D, Kasım Durmuş(i) and Emine Elif Altuntas (D)
}

\begin{abstract}
Background: The aim of the present study was to evaluate retrospectively the frequency of anatomical variations in sinonasal region, which were frequently seen in our cases, for whom coronal section paranasal computed tomography imaging (CPNCT) was taken, as well as the correlation of these variations with age and gender and correlations of identified anatomical variations with one another. In the study, CBCT scans of a total of 1532 (825 males and 707 females) cases were evaluated in order to determine the prevalence of anatomical variations of the nasal cavity and paranasal sinuses. All the images were taken by a multi-detector CT device (Aquilion, Toshiba medical system, Tokyo, Japan).

Results: Most frequently detected three anatomical variations were septum deviation (79.7\%), concha bullosa (40.9\%), and ethmoid bulla (21.0\%) according to the frequency order. When the frequency of anatomical variations was evaluated according to gender, septum deviation, concha bullosa, and anterior clinoid process pneumatization were more frequently observed in males and Onodi cell in females $(p<0.05)$.

When the relationships of the anatomical variations with one another were evaluated, it was found that the possibility of the presence of concha bullosa in the septum deviation cases and the presence of ethmoid bulla in the cases with Haller cell septum were higher $(p<0.05)$.

In terms of the anatomical variations that were evaluated by taking age as the independent variable, a statistically significant difference was observed in pterygoid process pneumatization, Haller cell, pneumatized crista galli, ethmoid bulla, and paradoxical middle concha between the adult and children age groups $(p<0.05)$.

Conclusion: In terms of the frequency of occurrence to various sinonasal region variations, statistically significant differences were observed between both genders and age groups. The correlations of the detected variations with each other were also remarkable. Consequently, it is believed that comprehensive studies and serious objective evaluations evaluating the change of frequency of anatomical variations according to age and gender besides their correlation with each other are required.
\end{abstract}

Keywords: Anatomical variation, Computed tomography, Sinonasal region, Age and gender

\footnotetext{
* Correspondence: adembora2016@gmail.com

Department of Otolaryngology, Faculty of Medicine, Sivas Cumhuriyet University, 58140 Sivas, Turkey
}

\section{Springer Open}

(0) The Author(s). 2021 Open Access This article is licensed under a Creative Commons Attribution 4.0 International License, which permits use, sharing, adaptation, distribution and reproduction in any medium or format, as long as you give appropriate credit to the original author(s) and the source, provide a link to the Creative Commons licence, and indicate if changes were made. The images or other third party material in this article are included in the article's Creative Commons licence, unless indicated otherwise in a credit line to the material. If material is not included in the article's Creative Commons licence and your intended use is not permitted by statutory regulation or exceeds the permitted use, you will need to obtain permission directly from the copyright holder. To view a copy of this licence, visit http://creativecommons.org/licenses/by/4.0/. 


\section{Background}

Traditional X-ray imaging methods are not recommended in the current guidelines that are published for the radiological evaluation of paranasal sinuses. If a diagnostic imaging study is required, it is recommended to use modern computed tomography (CT). However, today, the requirement of radiological imaging of paranasal sinuses in the diagnosis of sinus diseases is still controversial [1]. In this regard, it is important to follow certain guidelines to reduce the request for unnecessary diagnostic imaging from the patients [2]. It should be noted that $\mathrm{CT}$ imaging requests from the patients without any justification will cause unnecessary radiation exposure and increased cost to the healthcare system. CT imaging is indicated when the medical treatment is not successful, endoscopic sinus surgery is considered, or there is any suspected malignancy. The studies have revealed that CT imaging should be used in order to identify the anatomical variation and the disease pattern before the surgery, especially in the cases to whom endoscopic sinus surgery will be applied [3-6].

While different studies in the literature associate the anatomical variations detected in the CT evaluation of sinuses with specific sinonasal diseases or cystic fibrosis and clinical diseases such as Kartagener syndrome, they also reveal that significant anatomical variations can be observed in the cases with no diseases [7]. Whether the patient has a mucosal sinus disease or not, the presence of at least one sinonasal anatomical variation in the patients varies between $64.0 \%$ and $99.8 \%$ [7, 8]. Paranasal sinus pneumatization is a complex process that cannot be exactly understood. Numerous anatomical variations can be observed in this region as a result of a natural result of this complex process. Among the anatomical variations that are detected and frequently observed in paranasal CT imaging, nasal septum deviation, concha bullosa or paradoxical middle concha, ethmoidal bulla hypertrophy, agger nasi cell, lateral or medial localization of the uncinate process and Haller cell, and Onodi cell can be regarded [6]. Due to a wide range of anatomical variations in this region, there are numerous studies in the literature evaluating different perspectives on this issue. Even though there are numerous studies investigating the frequency of sinonasal variation in limited number of studies among the accessed databases, only a few studies examining the differences of these variations between genders could be reached [9-14]. In their study, Shokri et al. [9], the frequency of the anatomical variations observed in nasal cavity and ethmoidal sinuses by using cone-beam computed tomography, their differences according to gender and age, and the correlations between different variations were evaluated. From this point of view, the aim of the present study was to evaluate retrospectively the frequency of anatomical variations in sinonasal region, which were frequently seen in our cases, for whom coronal section paranasal computed tomography imaging (CPNCT) was taken in our clinic within a last 10-year period for any reason, as well as the correlation of these variations with age and gender and correlations of identified anatomical variations with one another.

\section{Methods \\ Study population}

The study was conducted on 1567 cases, who applied to Sivas Cumhuriyet University, Faculty of Medicine, Training, Research and Application Hospital, Otorhinolaryngology Clinic with sinonasal complaints between January 2009 and January 2019, whose CPNCT was taken during the diagnosis process, and who agreed to participate in the study. However, upon determination of sinusitis findings, 35 cases were excluded from the analysis and CPNCT findings of a total of 1532 cases were evaluated. Of the cases included in the study, 53.9\% ( $n=825)$ were male and $46.1 \%(n=707)$ were female.

CPNCT examination was performed in all the cases due to the suspicion of sinus pathology in their history or physical examination, and no radiological imaging specific to this study was requested.

The cases who had acute sinusitis findings underwent a surgical intervention for the nose and/or paranasal sinuses before, had a previous fascial trauma history, diagnosed with fibrous dysplasia, and had nasal polyp, inverted papilloma, or tumor-like mass lesion identified in anterior rhinoscopy and/or endoscopic examination and also did not accept to participate in the study were excluded from the study.

All the voluntary cases were informed by the researchers and their verbal and written consents were taken. Ethics committee approval of the study was obtained from the Non-invasive Ethics Committee of Sivas Cumhuriyet University Faculty of Medicine (Date: 13 November 2019; Decision No.: 2019-11/12).

\section{The evaluation of the paranasal CTs}

CPNCT images were evaluated by a senior otolaryngologist and the resident physician ( $\mathrm{AB}$ and $\mathrm{MK})$, who were also the authors of the study.

In all the cases, imaging was performed in prone position by using a 128-slice multi-detector CT device (Aquilion,Toshiba medical system,Tokyo, Japan) and a $120 \mathrm{Kv}, 150 \mathrm{mAs} ; 16 \mathrm{~mm} \times 0.75 \mathrm{~mm}$ detector collimation, and a section thickness of $5 \mathrm{~mm}$. The sections obtained were reconstructed at a 5-mm thickness in coronal plane in the bone window (W3000/L600).

The parameters evaluated in the paranasal sinus CT scan were as follows: 
1. Presence and direction of the nasal septum deviation

2. Upper and middle concha pneumatization

3. Agger nasi cell (ANC), Haller cell and Onodi cell, and ethmoidal cell variations including ethmoid bulla

4. Accessory pneumatization variations; pterygoid process, anterior clinoid, crista galli, and septum pneumatization

5. Uncinate bulla

6. Paradoxical middle concha

7. Curved uncinate process

In the examination of $\mathrm{CT}$ sections, the bone or cartilage spurs showing elongation to the nasal cavity and the septal pathologies that may cause nasal obstructions were evaluated as nasal septal deviation. Among the anatomical variations of the middle concha that were bullous, lamellar, and extensive concha bullosa, only the bullous form was accepted as concha bullosa. Conchae with the convexity oriented to the eye side were accepted as paradoxical middle concha, all the cells that showed invasion to the lower wall of the orbita and remained below the ethmoid bulla level were accepted as Haller cells, uncinate processes having internal air density were accepted as uncinate bulla, and the uncinate processes that significantly curves to the septum were accepted as curved uncinate process. Pneumatic cells constricting the frontal recess from the frontal sinus to sphenoid sinus in coronal plane before middle concha is observed were accepted as the agger nasi cells and if the free end of uncinate in any of the sections where uncinate process was observed was effused to the medial and inferior of the free end, this was accepted as hyperpneumatized ethmoid bulla. The cells growing to the posterior and lateral from the superior of sphenoid sinus by excessively growing from the posterior group ethmoid cells were recorded as the onodi cells. Even though the onodi cells were well-examined in the CT images in axial plane, the transverse septa in sphenoid sinus were named as the onodi cells in coronal plane CT. Pterygoid process is a protrusion formed of two lamina elongating from the junction site of sphenoid bone corpus and ala major on both sides and the hyperpneumatized appearance of the sphenoid bone within the ala protrusion was assessed as the pterygoid process pneumatization. Anterior clinoid process (ACP) is located in the medial end of the ala minor of the sphenoid bone and if there is a pneumatic cell inside, it was assessed as anterior clinoid process pneumatization. Elongation of the pneumatic cells from sphenoid sinus or crista galli to the septum was defined as pneumatized nasal septum $[8,9,15]$.

\section{Statistical analysis}

"Statistical Package for Social Sciences (SPSS) 23.0" statistical package program was used for statistical evaluation. Chi-square test was used for statistical analysis and significance test was used for the independent samples, and $p$ value of $<0.05$ was accepted as significant.

\section{Results}

\section{General evaluation of the study population}

Average age of 1532 cases included in the study was $33.74 \pm 14.50$ years ( $\min -\max : 7-89$ years). Of the cases included in the study, $53.9 \%(\mathrm{n}=825)$ were male [age average of $34.13 \pm 14.44$ years (min-max: $7-89$ years)] and $46.1 \%(\mathrm{n}=707)$ [age average of $33.31 \pm 14.56$ years (min-max: 9-85 years)] were female. The groups were statistically similar in terms of age and gender $(p>0.05$; $p=0.269$ ).

When CPNCT of all the cases included in the study was examined in terms of anatomical variations; an anatomical variation was detected in $96.7 \%$ (1482) of the cases, while no variation was found in $3.3 \%$ (50). According to the frequency sequence of the cases, it was determined that $79.7 \%(\mathrm{n}=1225)$ had septum deviation, 40.9\% ( $\mathrm{n}=628)$ had concha bullosa, $21.0 \%(\mathrm{n}=322)$ had ethmoid bulla, $16.9 \%(\mathrm{n}=259)$ had paradoxical middle concha, $16.4 \%(\mathrm{n}=251)$ had pneumatized crista galli, 15.3\% ( $\mathrm{n}=234)$ had Haller cell, $14.8 \%(\mathrm{n}=226)$ had agger nasi cell, $13.4 \%(\mathrm{n}=206)$ had anterior clinoid process, $8.1 \%(\mathrm{n}=124)$ had onodi cell, $4.5 \%(\mathrm{n}=69)$ had pterygoid process pneumatization, 3.2\% $(n=49)$ had curved uncinate process, $1.3 \%(\mathrm{n}=20)$ had septum pneumatization, and $0.2 \%(n=3)$ had uncinate bulla.

Table 1 shows the distribution of anatomical variations according to genders. When the frequency of anatomical variations was evaluated according to gender, the most frequently observed pathology was septum deviation similar to all the cases and it was more common in male cases than female ones and this difference was statistically significant $(p<0.05 ; p=0.012)$. Other anatomical variations observed with a statistically significant difference between the genders were concha bullosa $(p<0.05$; $p=0.019)$, anterior clinoid process pneumatization $(p<$ $0.05 ; p=0.016)$, and the presence of Onodi cell $(p<$ $0.05 ; p=0.043)$, respectively. Among these anatomical variations, only Onodi cell was more frequently observed in female cases; whereas, other two variations were more frequent in male ones. No statistically significant difference was observed in other anatomical variations in terms of gender $(p>0.05)$.

The correlations of the most frequently observed anatomical variations in all the cases included in the study with one another were evaluated. No statistically significant correlation was observed except for septum deviation-concha bullosa and Haller cell-ethmoid bulla. 
Table 1 The gender distribution of the paranasal CT scans

\begin{tabular}{|c|c|c|c|c|}
\hline \multirow[t]{2}{*}{ Anatomic variation } & & \multicolumn{2}{|l|}{ Gender } & \multirow{2}{*}{$\begin{array}{l}P \\
\text { value }\end{array}$} \\
\hline & & Man \%(n) & Woman \%(n) & \\
\hline \multirow[t]{4}{*}{ Septal deviation } & Median & $44.0(135)$ & $56.0(172)$ & 0.001 \\
\hline & Right & $54.4(318)$ & $45.6(267)$ & \\
\hline & Left & $58.3(314)$ & $41.7(225)$ & \\
\hline & S Deviation & $57.4(58)$ & $42.6(43)$ & \\
\hline \multirow[t]{2}{*}{ Agger nasi cells } & Negative & $53.3(696)$ & $46.7(610)$ & 0.292 \\
\hline & Positive & $57.1(129)$ & $42.9(97)$ & \\
\hline \multirow[t]{2}{*}{ Concha bullosa } & Negative & $51.4(466)$ & $48.6(440)$ & 0.019 \\
\hline & Positive & $57.5(361)$ & $42.5(267)$ & \\
\hline \multirow[t]{2}{*}{ Pneumatization of pterygoid process } & Negative & $53.9(789)$ & $46.1(674)$ & 0.775 \\
\hline & Positive & $52.2(36)$ & $47.8(33)$ & \\
\hline \multirow[t]{2}{*}{ Uncinate bulla } & Negative & $53.8(822)$ & $46.2(707)$ & NAN \\
\hline & Positive & $100.0(3)$ & $0.0(0)$ & \\
\hline \multirow[t]{2}{*}{ Haller cells } & Negative & $54.3(705)$ & $45.7(593)$ & 0.392 \\
\hline & Positive & $51.3(120)$ & $48.7(114)$ & \\
\hline \multirow[t]{2}{*}{ Pneumatization of anterior clinoid process } & Negative & $52.6(698)$ & $47.4(628)$ & 0.016 \\
\hline & Positive & $61.7(127)$ & $38.3(79)$ & \\
\hline \multirow[t]{2}{*}{ Onodi cell } & Negative & $54.6(769)$ & $45.4(639)$ & 0.043 \\
\hline & Positive & $45.2(56)$ & $54.8(68)$ & \\
\hline \multirow{2}{*}{$\begin{array}{l}\text { Pneumatization of crista } \\
\text { galli }\end{array}$} & Negative & $53.6(687)$ & $46.4(595)$ & 0.603 \\
\hline & Positive & $55.4(139)$ & $44.6(112)$ & \\
\hline \multirow[t]{2}{*}{ Pneumatization of nasal septum } & Negative & $53.7(813)$ & $46.3(700)$ & 0.577 \\
\hline & Positive & $60.0(12)$ & $40.0(8)$ & \\
\hline \multirow[t]{2}{*}{ Ethmoid bulla } & Negative & $54.2(656)$ & $45.8(554)$ & 0.580 \\
\hline & Positive & $52.5(169)$ & $47.5(153)$ & \\
\hline \multirow[t]{2}{*}{ Paradox middle concha } & Negative & $53.7(683)$ & $46.3(590)$ & 0.730 \\
\hline & Positive & $54.8(142)$ & $45.2(117)$ & \\
\hline \multirow[t]{2}{*}{ Deviation of uncinate process } & Negative & $53.8(798)$ & $46.2(685)$ & 0.858 \\
\hline & Positive & $55.1(27)$ & $44.9(22)$ & \\
\hline
\end{tabular}

Note: Number of cases with uncinate bulla $n=3$ (male)

Since number of cell elements does not meet the condition of $n>5$, statistical evaluation was not carried out

When the correlation between septum deviation and concha bullosa was examined, it was shown that the probability of concha bullosa was lower in the cases without septum deviation, and higher in the cases with septum deviation. When the correlation between septum deviation and concha bullosa was evaluated, the difference was found as statistically significant $(p<0.05 ; p=$ 0.031). Also, in the cases with septum deviation toward the right side, the probability of concha bullosa was statistically higher than the cases with S-type and deviation toward left $(p<0.05 ; p=0.031)$. The possibility of the combined presence of septum deviation and concha bullosa was $33.25 \%$. When the correlation between the Haller cell and ethmoid bulla was examined, it was found that the possibility of ethmoid bulla was statistically lower in the cases without Haller cell $(p<0.05 ; p=$ 0.001 ). The possibility of the combined presence of Haller cell and ethmoid bulla was $12.8 \%$ (Fig. 1).

\section{Evaluation of the study population in terms of pediatric and adult age groups}

When 1532 cases included in the study were evaluated by dividing them in two groups as $<18$ years old (pediatric group; group $\mathrm{P}$ ) and $\geq 18$ years old (adult group; group A), the results were presented below.

Average age of $134(8.7 \%)$ cases in group $\mathrm{P}$ was 16.62 \pm 2.10 years (min-max: $7-18$ years) and average age of $1398(91.3 \%)$ cases in group A was $35.39 \pm 14.11$ years (min-max: $19-89$ years). In group P, 45.5\% $(\mathrm{n}=61)$ of the cases were male [average age of $16.84 \pm 2.02$ years 


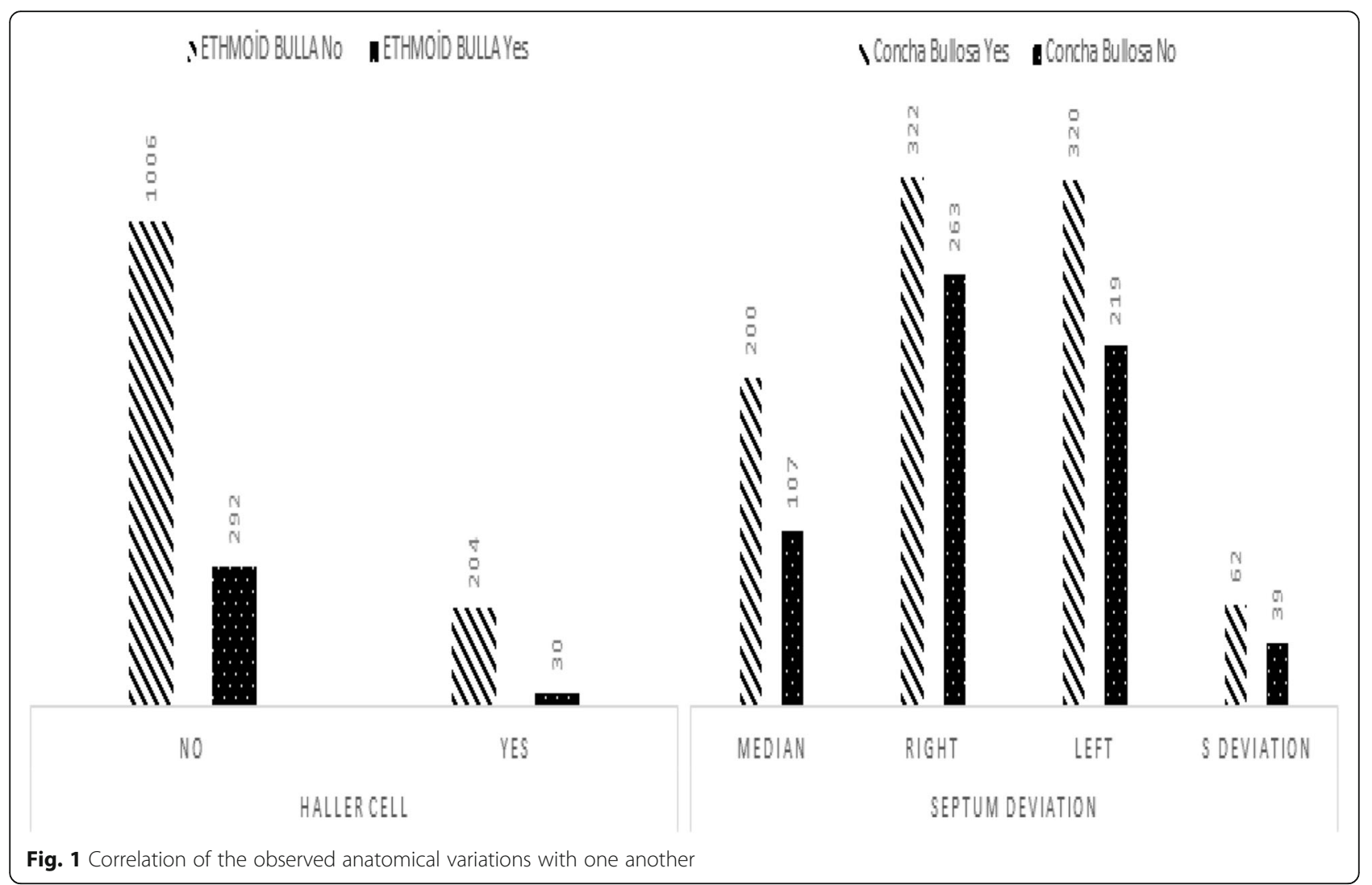

(min-max: $7-18$ years)] and 54.5\% $(\mathrm{n}=73)$ [average age of $16.44 \pm 2.17$ years (min-max: 9-18 years)] were female. In group A, 54.6\% ( $\mathrm{n}=764)$ of the cases were male [average age of $35.51 \pm 14.01$ years (min-max: 1989 years $)$ ] and $45.4 \%(n=634)$ [age average of $35.25 \pm$ 14.12 years (min-max: $19-85$ years)] were female. It was seen that both groups were statistically similar in terms of gender $(p>0.05)$.

When the CPNCTs of the cases both in group $\mathrm{P}$ and group A were examined in terms of anatomical variations; variation was present in a total of 132 (98.5\%) patients in group $\mathrm{P}$, while no variation was found in 2 (1.5\%). In group A, while variation was present in a total of $1350(96.6 \%)$ patients, no variation was observed in 48 (3.3\%) of the cases. Table 2 shows the distribution of the anatomical variations observed in group $\mathrm{P}$ and group $\mathrm{A}$.

When age was considered as the independent variable; a statistically significant difference was observed between the two groups in pterygoid process pneumatization $(p<$ 0.05 ; $p=0.030)$, Haller cell $(p<0.05$; $p=0.017)$, pneumatized crista galli $(p<0.05 ; p<0.001)$, ethmoid bulla $(p<0.05 ; p=0.024)$, and paradoxical middle concha $(p$ $<0.05$; $p=0.003$ ) between both groups in terms of the anatomical variations $(p<0.05)$. Similarly, in the current study, when age was considered as the independent variable, anatomical variations were evaluated according to gender and they are found more in females under 18 years old $(\mathrm{n}=73 ; 54.5 \%)$ and males over 18 years old ( $\mathrm{n}$ $=764 ; 54.7 \%$ ). However, a statistically significant difference was found due to this difference in distribution ( $p$ $<0.05 ; p=0.043)$. Also, it is thought that there was no bias in population representation in terms of demographic characteristics, as the number of participants in the study exceeded the maximum sample size.

\section{Discussion}

Sinonasal region is a region where anatomical variations are mostly seen. Such variations in the sinonasal region form a basis for development of numerous sinus diseases. Thus, it is crucial to know and evaluate the variations observed in this region during the diagnosis and treatment phase. Rates of the anatomical variations in sinonasal region varied between 64.0 and $99.8 \%$ in the studies conducted $[7,8,15,16]$. In the current study, at least one anatomical variation was detected in $96.7 \%$ of the cases and the results are similar with the literature. It should be noted that the distribution of the rates of anatomical variations in such a wide range may be caused by the differences in the variation classification, ethnic origin, difference in the weight rates of the genders, difference in the imaging method used in evaluation, and the difference in the population size.

Today, CPNCT steps forth as the ideal imaging method for the evaluation of the anatomy of sinonasal 
Table 2 Distribution of anatomical variations in pediatric and adult age groups

\begin{tabular}{|c|c|c|c|c|}
\hline \multirow[t]{2}{*}{ Anatomical variation } & & \multicolumn{2}{|l|}{ Group } & \multirow[t]{2}{*}{ p } \\
\hline & & Group P \% (n) & Group A \% (n) & \\
\hline \multirow[t]{4}{*}{ Septal deviation } & Median & $3.9(12)$ & $96,1(295)$ & 0.662 \\
\hline & Right & $4.6(27)$ & $95,4(558)$ & \\
\hline & Left & $5.8(31)$ & $94,2(508)$ & \\
\hline & S Dev. & $5(5)$ & $95(96)$ & \\
\hline \multirow[t]{2}{*}{ Agger nasi cells } & Negative & $4.7(62)$ & $95,3(1244)$ & 0.518 \\
\hline & Positive & $5.8(13)$ & $94,2(213)$ & \\
\hline \multirow[t]{2}{*}{ Concha bullosa } & Negative & $5(45)$ & $95(859)$ & 0.858 \\
\hline & Positive & $4.8(30)$ & $95,2(598)$ & \\
\hline \multirow[t]{2}{*}{ Pneumatization of pterygoid process } & Negative & $4.7(69)$ & $95,3(1394)$ & 0.134 \\
\hline & Positive & $8.7(6)$ & $91,3(63)$ & \\
\hline \multirow[t]{2}{*}{ Uncinate bulla } & Negative & $4.9(75)$ & $95,1(1454)$ & 0.694 \\
\hline & Positive & $0(0)$ & $100(3)$ & \\
\hline \multirow[t]{2}{*}{ Haller cells } & Negative & $5.2(68)$ & $94,8(1230)$ & 0.143 \\
\hline & Positive & $3(7)$ & $97(227)$ & \\
\hline \multirow[t]{2}{*}{ Pneumatization of anterior clinoid process } & Negative & $4.8(64)$ & $95,2(1262)$ & 0.751 \\
\hline & Positive & $5.3(11)$ & $94,7(195)$ & \\
\hline \multirow[t]{2}{*}{ Onodi cell } & Negative & $5(70)$ & 95 (1338) & 0.642 \\
\hline & Positive & $4(5)$ & $96(119)$ & \\
\hline \multirow[t]{2}{*}{ Pneumatization of crista galli } & Negative & $4.1(53)$ & $95,9(1228)$ & 0.002 \\
\hline & Positive & $8.8(22)$ & $91,2(229)$ & \\
\hline \multirow[t]{2}{*}{ Pneumatization of nasal septum } & Negative & $4.8(73)$ & $95,2(1439)$ & 0.287 \\
\hline & Positive & $10(2)$ & $90(18)$ & \\
\hline \multirow[t]{2}{*}{ Ethmoid bulla } & Negative & $5.3(64)$ & $94,7(1146)$ & 0.166 \\
\hline & Positive & $3.4(11)$ & $96,6(311)$ & \\
\hline \multirow[t]{2}{*}{ Paradox middle concha } & Negative & $4.4(56)$ & $95,6(1217)$ & 0.046 \\
\hline & Positive & $7.3(19)$ & $92,7(240)$ & \\
\hline \multirow[t]{2}{*}{ Deviation of uncinate process } & Negative & $5(74)$ & 95 (1409) & 0.347 \\
\hline & Positive & $2(1)$ & $98(48)$ & \\
\hline
\end{tabular}

Group P: pediatric age groups ( $<18$ age)

Group A: adult age groups ( $\geq 18$ age)

region and the anatomical variations. Especially for the doctors conducting endoscopic sinus surgeries, it provides useful information for the detailed evaluation of the anatomical structures before the surgery and also increases the safety of the surgical procedure [17].

One of the most common variations of the sinonasal region is the deviation of the nasal septum and it is the deviation of the septum toward right and/or left from the midline. Different studies in the literature have reported that the prevalence of nasal septum deviation varied between $20 \%$ and $79 \%$ [18]. In the current study, nasal septum deviation was higher than the prevalence range stated in the literature and it was $79.7 \%$. Also, it was more frequently observed in male cases than females when evaluated in terms of genders. The study conducted by Günay et al. [17] in Turkey, to evaluate the prevalence of sinonasal variation and the differences between the genders, the most frequently observed anatomical variation was detected as the presence of Agger nasi cell. However, they point outed that Agger nasi cell was not accepted as a variation due to its high frequency, but as a normal variant. The second most frequently seen variation was nasal septum deviation which was the most frequent variation in the current study. However, unlike the present study, no significant difference was found between the genders in that study. Since many environmental and genetic factors play a role in the formation of septal deviation, it is inevitable that different results have been obtained in the studies. It is thought that the high rate obtained in the present study 
may be caused by the ethnic origin. Furthermore, it is thought that high deviation observed in male cases in the present study may be a result of more exposure of men to traumas in developing countries like Turkey. The fact that the difference detected in prevalence of nasal septum deviation in terms of genders in the present study was different from Günay et al.'s [17] study cannot be explained by the emphasis of ethnic origin in the present study without doubt. However, it is considered that the difference in the results of two studies conducted in Turkey is a normal result of the larger population density evaluated in the current study. If the sample group is enlarged as in other study, the results may be similar.

The results of the studies evaluating the correlation between septum deviation and other anatomical variations also show differences with each other. For example, while it is noted in some studies that there is a correlation between septum deviation and sinusitis, different studies have reported that there is no correlation on this issue [12, 19-21]. Likewise, it is highlighted in the literature that there is a correlation between nasal septum deviation and concha bullosa $[9,10,22]$. In a study, a significant correlation was shown between the presence of concha bullosa and the deviation of septum to the opposite side [21]. In the present study, it was observed that cases with septal deviation were more likely to have concha bullosa.

A wide distribution range is present in the studies evaluating the prevalence of nasal septum deviation according to age. When the results of the literature studies are taken into consideration, this rate varies between $0.93 \%$ and $60 \%$ in newborns and is between $1.5 \%$ and $13.6 \%$ in older children. Quite wide prevalence range in adults can be explained by the differences in the age groups of the evaluated cases, the classifications used for the identification of septum deviation, and diagnosis methods [23]. In their study, Reitzen et al. [23], evaluated frequency of nasal septum deviation in adult and children age groups and concluded that nasal septum deviation was more frequently observed in older children and adults. According to the results, they emphasized that no conclusion could be made regarding the lack of a definitive correlation between septum deviation and genetic predisposition. The results obtained in the study showed that there was no correlation between age and nasal septum deviation. Although the results of the present study were not compatible with the results of the study by Reitzen et al. [23], it is thought that this difference is a natural result of the classification of all cases by the same doctors and by using the same method.

The most frequently observed middle concha variation is the concha bullosa. Prevalence of concha bullosa varies between $35 \%$ and $53 \%$ [10, 24]. In the study by Smith et al. [24], this rate was $67.5 \%$, while it was found as $71.6 \%$ in the study by Aykut [25]. In the present study, the prevalence of concha bullosa was compatible with the literature and it was found as $40.9 \%$. In the literature, a limited number of studies are present that investigate the frequency of concha bullosa among the genders. In their study, Günay et al. [17] found the rate of concha bullosa as $41 \%$ in females and $33 \%$ in males. In the present study, concha bullosa was detected in $42.5 \%$ of females and in $57.5 \%$ of males, and this difference was found to be statistically significant. In the study conducted by Cohen et al. [26], to evaluate the change in the prevalence of concha bullosa with increasing age, although it was determined that the incidence of concha bullosa increased with increasing age, this difference was not detected in the present study.

The other variations for which statistically significant difference was determined in the evaluation of anatomical variations of sinonasal region based on gender in the present study were the presence of anterior clinoid process pneumatization and Onodi cell. The prevalence of the Onodi cell varies according to the evaluation method. While the prevalence of Onodi cells detected during endoscopic examination was $14-39 \%$, it was 8 $7 \%$ when detected by CT [27]. When ethnic origin was considered in the prevalence, the prevalence of Onodi cell in Asian subjects is higher than the prevalence reported in European countries regardless of the identification method [28]. In the assessment conducted by CT, Chmielik et al. [27] reported the prevalence of onodi cell as $39.8 \%$. In the present study, this rate was detected as $8.1 \%$, which is compatible with the literature. When this variation was evaluated based on gender, Günay et al. [17] detected it as $11 \%$ for females and $7 \%$ for males in their study and no significant difference was observed in terms of gender. In their study, Ali et al. [29] found this rate as $43.3 \%$ in females and $42.3 \%$ in males and despite the high prevalence, they concluded that there was no difference between genders. In the present study, Onodi cell was detected in $54.8 \%$ of females and $45.2 \%$ of males. Although the prevalence was high in the present study, the results were similar to the results of the study by Ali et al. [29]. The presence of Onodi cell is affected by numerous factors, as in other anatomical variations. However, it is believed that possible reasons underlying the higher prevalence in females should be further investigated in the future.

It is suggested that Haller cells may also cause maxillary sinusitis by disrupting the mucociliary flow and causing obstruction in the osteomeatal complex [30]. These cells are located in the medial of infraorbital canal and in the lateral of nasolacrimal canal. The prevalence of Haller cells varies between $4.7 \%$ and $78 \%$ [31]. In the present study, the prevalence of Haller cells was found 
as $15.3 \%$. In the literature, the prevalence of ethmoid bulla shows a wide distribution range and its frequency varies between $10 \%$ and $89 \%$ in the reported publications $[32,33]$. In the present study, the prevalence of ethmoid bulla was $21 \%$ and no difference was found between the genders in terms of ethmoid bulla as in the Haller cell. The wide range of Haller cell and ethmoid bulla prevalence in the literature can be certainly caused by many factors such as the imaging method used, differences in the identification of variation, number of patients evaluated, different age groups, and ethnic differences. However, no difference was detected between both genders in terms of the presence of both anatomical variations in the present study. When age was taken as an independent variable, a statistically significant difference was found for both anatomical variations in children and adult age groups. Not only the prevalence of these two variations, but also the prevalence of pterygoid process pneumatization, pneumatized crista galli, and paradoxical middle concha increases with increasing age. For this reason, it is considered that studies using more comprehensive different imaging methods should be conducted in the future in order to clarify the question "Why are these variations seen more frequently with increasing age?"

When the correlations between Haller cells and other anatomical variations of the sinonasal region were evaluated, a correlation was shown to be present between nasal septum deviation and the presence of the cell $[8$, 9]. In the present study, no similar correlation was shown between Haller cells and septum deviation; however, the possibility of ethmoid bulla in the cases with Haller cell was shown to be $12.8 \%$. No study could be reached that remarks the correlation between the Haller cell and ethmoid bulla. Since this correlation may be related to the embryological development of the nasal lateral wall, it is considered that it may be useful to deepen the related studies in the future.

\section{Conclusion}

The results of the studies in the literature evaluating the frequency of anatomical variations in the sinonasal region via different methods have showed a wide distribution range. Many factors definitely cause this. However, the studies in the literature draw more attention to the difference in gender and age distribution among these factors. In the present study, the frequency of the anatomical variations according to both age and gender factors and their correlation with each other were tried to be evaluated in a very large case series. The results obtained showed that among the anatomical variations, concha bullosa and anterior clinoid process pneumatization were mostly seen in male cases and Onodi cell in female cases. Another important finding was the increase in the prevalence rates of pterygoid process pneumatization, Haller cell, pneumatized crista galli, ethmoid bulla, and paradoxical middle concha with increasing age.

Based on the results of the study, statistically significant differences were detected between both genders and age groups in terms of the frequency of various sinonasal region variations. While some of the results of the present study are compatible with the literature, some are different. Also, the correlations of the detected variations with each other are also remarkable. Consequently, it is believed that further studies and serious objective evaluations are required for this subject.

\section{Abbreviations \\ CT: Computed tomography; CPNCT: Coronal section paranasal computed tomography imaging; ANC: Agger Nasi Cell; ACP: Anterior clinoid process; SPSS: Statistical Package for Social Sciences}

\section{Acknowledgements}

We would like to thank Selim Çam for his contribution to statistical evaluation.

\section{Authors' contributions}

Concept-E.E.A, A.B., K.D.; design-E.E.A, K.D., A.B.; supervision-E.E.A, A.B., K.D.; resource-E.E.A; materials-A.B., M.K.; data collection and/or processing-A.B., K.D. M.K.; analysis and/or interpretation-E.E.A, A.B.; literature search-K.D., A.B. M.D.; writing-E.E.A, A.B.; critical reviews-E.E.A, K.D., A.B. All authors have read and approved the final manuscript.

\section{Funding}

None

Availability of data and materials

The datasets used and/or analysed during the current study are available from the corresponding author on reasonable request.

\section{Declarations}

Ethics approval consent to participate

Ethics approval of this study was obtained from Cumhuriyet University Clinical Trials Ethics Committee (dated 13.11.2019; with decision no. 2019-11/ 12). Written informed consent was obtained from the patients and parents/ guardians of patients under 16 years old who participated in this study.

Consent for publication

All authors confirm that a written consent form is received for the information and documents used from the patients and/or their families. Written and/or verbal consent forms were obtained from the subjects included in the study.

\section{Competing interests}

The authors declare that they have no competing of interests.

Received: 1 March 2021 Accepted: 20 May 2021

Published online: 05 June 2021

\section{References}

1. Ling FT, Kountakis SE (2007) Important clinical symptoms in patients undergoing functional endoscopic sinus surgery for chronic rhinosi-nusitis. Laryngoscope. 117(6):1090-1093. https://doi.org/10.1097/MLG.0b013e31804 b1a90

2. Pennell DJL, McClelland E, Sayer C, Bhutta MF, Watts SJ (2019) A local guideline reduces inappropriate requests for computed tomography imaging of the paranasal sinuses. Clin Otolaryngol 44(6):1128-1130. https:// doi.org/10.1111/coa.13411 Epub 2019 Oct 2. PMID: 31389173 
3. Jiannetto DF, Pratt MF (1995) Correlation between preoperative computed tomography and operative findings in functional endoscopic sinus surgery. Laryngoscope. 105(9):924-927. https://doi.org/10.1288/00005537-19950900000010

4. Nitinavakarn B, Thanaviratananich S, Sangsilp N (2005) Anatomical variations of the lateral nasal wall and paranasal sinuses: a CT study for endoscopic sinus surgery (ESS) in Thai patients. J Med Assoc Thail 88(6):763-768 PMID: 16083216

5. Bayram M, Sirikci A, Bayazit YA (2001) Important anatomic variations of the sinonasal anatomy in light of endoscopic surgery: a pictorial review. Eur Radiol 11(10):1991-1997. https://doi.org/10.1007/s003300100858

6. Fadda GL, Rosso S, Aversa S, Petrelli A, Ondolo C, Succo G (2012) Multiparametric statistical correlations between paranasal sinus anatomic variations and chronic rhinosinusitis. Acta Otorhinolaryngol Ital 32(4):244251

7. Marino MJ, Riley CA, Wu EL, Weinstein JE, Emerson N, McCoul ED (2020) Variability of paranasal sinus pneumatization in the absence of sinus disease. Ochsner J 20(2):170-175. https://doi.org/10.31486/toj.19.0053

8. Dasar U, Gokce E (2016) Evaluation of variations in the sinonasal region with computed tomography. World J Radiol 8(1):98-108. https://doi.org/10.4329/ wjr.v8.11.98

9. Shokri A, Faradmal MJ, Hekmat B (2019) Correlations between anatomical variations of the nasal cavity and ethmoidal sinuses on cone-beam computed tomography scans. Imaging Sci Dent 49(2):103-113. https://doi. org/10.5624/isd.2019.49.2.103 Epub 2019 Jun 24

10. Bolger WE, Butzin CA, Parsons DS (1991) Paranasal sinus bony anatomic variations and mucosal abnormalities: $C T$ analysis for endoscopic sinus surgery. Laryngoscope. 101(1 Pt 1):56-64. https://doi.org/10.1288/0000553 7-199101000-00010

11. Messerklinger W (1967) On the drainage of the frontal sinüs of man. Acta Otolaryngol 63(2-3):176-181. https://doi.org/10.3109/00016486709128748

12. Stammberger H (1985) Endoscopic surgery for mycotic and chro- nic recurring sinusitis. Ann Otol Rhmol Laryngol (Suppi) 94:I-14

13. Lloyd GAS, Lund VJ, Scadding GK (1991) CT of the paranasal sinuses and functional endoscopic surgery: a critical analysis of 100 symptomatic patients. J Laryngol Otol 105:181-185. https://doi.org/10.1017/S00222151 00115300

14. Başak S (1993) The role of intranasal anatomical differences and osteomeatal unit in paranasal sinus diseases. Specialization Thesis, Cumhuriyet University Faculty of Medicine: Sivas 22-31

15. Koo SK, Kim JD, Moon JS, Jung SH, Lee SH (2017) The incidence of concha bullosa, unusual anatomic variation and its relationship to nasal septal deviation: a retrospective radiologic study. Auris Nasus Larynx 44(5):561-570. https://doi.org/10.1016/j.anl.2017.01.003

16. Earwaker J (1993) Anatomic variants in sinonasal CT. Radiographics. 13(2): 381-415. https://doi.org/10.1148/radiographics.13.2.8460226

17. Günay BT, Hayırlıoğlu A, Günay FB (2015) Cinsiyetler arasındaki sinonazal varyasyon sıklığının paranazal sinüs tomografisi ile değerlendirilmesi. Medeniyet Med J 30(1):26-34. https://doi.org/10.5222/MMJ.2015.026

18. Mundra RK, Gupta Y, Sinha R, Gupta A (2014) CT scan study of influence of septal angle deviation on lateral nasal wall in patients of chronic rhinosinusitis. Indian J Otolaryngol Head Neck Surg 66(2):187-190. https:// doi.org/10.1007/s12070-014-0713-7 Epub 2014 Mar 25

19. Lerdlum S, Vachiranubhap B (2005) Prevalence of anatomic variation demonstrated on screening sinus computed tomography and clinical correlation. J Med Assoc Thail 4:110-115

20. Kim HJ, Jung Cho M, Lee JW, Tae Kim Y, Kahng H, Sung Kim H, Hahm KH (2006) The relationship between anatomic variations of paranasal sinuses and chronic sinusitis in children. Acta Otolaryngol 126(10):1067-1072. https://doi.org/10.1080/00016480600606681

21. Stallman JS, Lobo JN, Som PM (2004) The incidence of concha bullosa and its relationship to nasal septal deviation and paranasal sinus disease. AJNR Am J Neuroradiol 25(9):1613-1618

22. Som PM, Curtin HD (2011) Head and neck imaging, 5th edn. Mosby Elsevier, St. Louis

23. Reitzen SD, Chung W, Shah AR (2011) Nasal septal deviation in the pediatric and adult populations. Ear Nose Throat J 90(3):112-115. https://doi.org/1 $0.1177 / 014556131109000308$

24. Smith KD, Edwards PC, Saini TS, Norton NS (2010) The prevalence of concha bullosa and nasal septal deviation and their relationship to maxillary sinusitis by volumetric tomography. Int J Dent 2010:404982. https://doi. org/10.1155/2010/404982 Epub 2010 Aug 24, 5

25. Aykut M (1994) Sinonasal variations and CT. Specialization Thesis, Cumhuriyet University Faculty of Medicine: Sivas; 20-40.

26. Cohen O, Adi M, Shapira-Galitz Y, Halperin D, Warman M (2019) Anatomic variations of the paranasal sinuses in the general pediatric population. Rhinology. 57(3):206-212. https://doi.org/10.4193/Rhin18.193

27. Chmielik LP, Chmielik A (2017) The prevalence of the Onodi cell - most suitable method of CT evaluation in its detection. Int J Pediatr Otorhinolaryngol 97:202-205. https://doi.org/10.1016/j.ijporl.2017.04.001 Epub 2017 Apr 4

28. Kasemsiri P, Thanaviratananich S, Puttharak W (2011) The prevalence and pattern of pneumatization of Onodi cell in Thai patients. J Med Assoc Thail 94(9):1122-1126

29. Ali IK, Sansare K, Karjodkar F, Saalim M (2020) Imaging analysis of Onodi cells on cone-beam computed tomography. Int Arch Otorhinolaryngol 24(3):e319-e322. https://doi.org/10.1055/s-0039-1698779 Epub 2019 Dec 13

30. Mathew R, Omani G, Hand A, Fellows D, Lurie A (2013) Cone beam CT analysis of Haller cells: prevalence and clinical significance. DenTomaxillofac Radiol 42(9):20130055. https://doi.org/10.1259/dmfr.20130055

31. Shruthi P, Ahmed J, Ongole R, Denny C, Shenoy N (2018) Clinical significance of haller cells: a cone beam computed tomography study. World J Dent 9(3):225-230

32. Alsowey AM, Abdulmonaem G, Elsammak A, Fouad Y (2017) Diagnostic performance of multidetector computed tomography (MDCT) in diagnosis of sinus variations. Pol J Radiol 82:713-725. https://doi.org/1 $0.12659 /$ PJR.903684

33. Fadda GL, Rosso S, Aversa S et al (2012) Multiparametric statistical correlations between paranasal sinus anatomic variations and chronic rhinosinusitis. Acta Otorhinolaryngol Ital 32(4):244-245

\section{Publisher's Note}

Springer Nature remains neutral with regard to jurisdictional claims in published maps and institutional affiliations.

\section{Submit your manuscript to a SpringerOpen ${ }^{\circ}$ journal and benefit from:}

- Convenient online submission

- Rigorous peer review

- Open access: articles freely available online

- High visibility within the field

- Retaining the copyright to your article

Submit your next manuscript at $>$ springeropen.com 